\title{
景观与建筑设计中的语言 \\ ISSUE ON THE LANGUAGES \\ IN LANDSCAPE AND \\ ARCHITECTURAL DESIGN
}

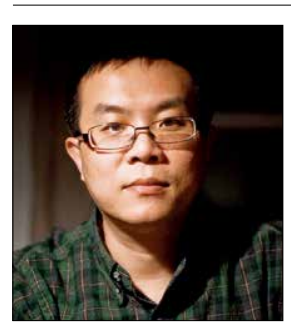

金秋野

北京建筑大学建筑与城市规划学院教授; 建筑评论家

北京市西城区展览馆路1号北京建筑大学建筑与城市规划学院,

邮编 : 100044

j inqi uye@bucea.edu.cn

Qiuye JIN

Professor of School of Architecture and Urban Planning, Beijing University of Civil Engineering and Architecture; Architectural Critic

请问您如何看待建筑与景观、人与自然 的关系?

金秋野（以下简称金）：这是一个极 其巨大的问题，人和自然的关系是根本。人 之所以为人, 是因为人可以使用工具。现在 我们的交流基本都在借助工具，比如眼镜、 镜头，可以说，自从人成为人开始，身体的 “工具化”过程就从未停止过。同时，机器 和人的双向交流过程一直在加深，界线也越 来越模糊, 工具、机器已经越来越人性化, 拥有越来越强大的感知和反应能力, 成为 人工智能。人和客观世界之间的鸿沟在逐 渐抹平。

反过来谈建筑与景观，东方的传统建筑 与景观就是身体的延伸, 它们一层层地与自 然产生联系，没有确定的边界。人在开着门 窗的房子里，墙上挂着山水图，案头摆着盆 景，屋外有园林，远望有山，每层都是人与 环境的直接关照和交流，这是文化符号的交 流、身体的交流和知觉的交流。建筑塑造了
不同的身体层次，成为身体与自然的中介。 建筑师的实践实际上建立起了人与物质世界 之间的交流。

那究竟什么是自然? 在哲学层面, 自然 是大化流行, 是运转, 是变化。原始的刀耕 火种比传统的手工艺技法更“自然”，而今 天的怀旧者却只懂捍卫手工技法。必须认识 到, 今天的工具、机器冰冷而缺乏生气, 这 种“异物感” 1 是工具、机器比较低级的状 态, 早晚有一天它们可以像我们身体一样, 经过时间和系统的篮选成为“自然”变化的 结果, 成为身体直接的延伸, 这是不可避免 的趋势。

在您看来, 景观评论和建筑评论是否有 异同?

金：建筑是物质的，最终总会消失，但 文字会传留。我从来不认为建筑评论是一种 专门的评论, 其形成是因为在建筑领域里有 一群人一直非常认真地把自己的感想整理成
https://doi.org/10.15302/J-LAF-20170606 | 采访时间 INTERVIEWED DATE / 2017-10-26 中图分类号 / TU2, HO5 文献标识码 / B
摘要

本次访谈围绕人与自然的关系、设计与评论的价值观等问题展开。受 访者金秋野认为，评论需要具备完整的生命意识，不拘泥于固定的文体表 达，是评论者以自身的历史知识和对时间的理解做出的理性判断，目的在 于表达评论者独立的价值观。他指出, 真正好的建筑师, 其设计过程是从 视觉到视觉的，超越了语言搭建的世界。

关键词

建筑评论; 景观评论; 设计语言; 批判思维

\section{ABSTRACT}

This interview centers on the relationship between human and nature, and the philosophy of architectural design and criticism. Qiuye Jin, the interviewee, believes that design criticism needs to reflect a complete life consciousness, which should not rigidly adhere to certain literary forms; a critique expresses the critic's philosophy and critical thinking based on his / her historical knowledge and own understanding of time. Jin also believes that a good architect can go beyond words, whose design work is visually constructed and conducted, and can speak itself.

KEY WORDS

Architectural Criticism; Landscape Criticism; Design Language; Critical Thinking

采访 余依爽 田晓劼 王楠

整理 余依爽 田晓动 田乐

译 田乐

INTERVIEWED BY Yishuang SHE Xiaojie TIAN Nancy WANG

EDITED BY Yishuang SHE Xiaojie TIAN TINa TIAN

TRANSLATED BY Tina TIAN 
理论化的语言。每个人都有感想, 但不一定 能成为评论, 如果感想被理智化了, 成为了 可传达的观点, 它就成为了评论。但是经过 整理的东西并不一定比口头说的好，比如把 央视大楼比喻为“大裤衩”，我觉得这种起 外号的能力特别厉害, 在这方面, 街头巷尾 的大爷大叔也许更厉害, 没有必要把评论这 件事看得特别了不起。

\section{您认为好的建筑评论是什么样的？}

金: 我在《建筑学报》上发表的《建筑 评论的文体问题》 ${ }^{[1]}$ 说得很清楚, 好的建筑 评论观点清晰, 文字好, 没有套路化, 且不 是传统意义上的建筑专业评论。千万不要给 建筑评论设定一个文体。评论是一种文学形 式，技巧是不能教的，是需要非常敏锐的感 受力以及很好的语言能力来展现的。现在的 研究太讲客观, 分析到最后就会很干涩, 论 据很充分，注释也非常清楚，但最后的观点 不是一个整体, 被肢解得不得了。我一直强 调评论需要一个完整的生命意识, 要有自己的 是非观和感想, 用真情实感让文章活起来。

其实，真正的批评家是时间，就像世界 上曾存在无数的物种，但最后经过时间考验 留存下来的只是很小的一部分，一切传播的 东西都要被时间检验。人类过滤无关信息的 能力非常强，时间会把没有生命力的东西全 部淘汰。

您曾经说过评论在某种程度上就是赞同

异物感是指当今人造环 境的抽象化和去自然化 给人造成的总体感觉。
金：这是我引用文学家黄灿然的一句 话，是非常讨巧的。除了指出好的设计之 外，评论还有另一个作用，就是能够把别人 都说好的东西, 说清楚它为什么不好。很多 垃圾是以非常美好的面貌出现的，评论的任 务之一就是把垃圾识别出来, 用清晰的语言 说明，然后把它剔除掉，这个事很难。

虽然对于“好”的标准非常多元化， 但从历史上看，这些标准还是相对客观和统 一的。在中国，一提诗词，我们就会想到李 白、杜甫、白居易、苏轼，是这些人定义了 诗歌, 定义了我们的思维。每个人心里都偷 偷摸摸地住着李白和苏轼。诗人拓展语言， 哲学家守护思维，诗人是前锋，哲学家是后 卫，每个艺术领域的发展都靠这两类人。所 以，好的诗人、艺术家、评论者实际上是在 一个大的历史语言里面去进行选择和判断, 而非凭空做事。好的作品在选择定位的同时 也在抗衡，在抗衡中找到新的生命力，加之 时间的洗礼，留下来的就形成了历史坐标轴 中新的参考系，也就成为了“好”。所以， 好的建筑师心里一定是有一部建筑史的。 评论者在选择立场或者态度的时候，实际 上也带着评论者自身的历史意识和对时间 的理解。

您发表了很多关于勒・柯布西耶和阿尔 瓦・阿尔托的翻译著作和理论评价, 您的建 筑价值观是否以他们为参照? 您最近翻译出 版的《勒. 柯布西耶: 为现代而生》 ${ }^{[3]}$ 是否 可以解读为对经典的致敬和期待读者的深 入解读?

金：20世纪初期，很多重要的建筑师提
出问题, 并尝试用设计来回答自己的困惑, 给我们提供了很多看问题的视角。虽然有些 现代的问题他们没有遇到，比如空气污染， 但阿尔瓦·阿尔托对人和自然的关系进行了 很多思考，一直在寻找平衡，他的思考和设 计实际已经包含着解答。

我把《勒. 柯布西耶：为现代而生》定 位为畅销书，初衷是想让大众知道这个人很 重要。大家都知道达利、毕加索、柴可夫斯 基等现代艺术大师，但是少有人知道勒．柯布 西耶，建筑界对大众发言的愿望还是太少， 力度还是太小。所以我选了关于勒. 柯布西 耶可读性最强的传记进行翻译。书里讲了很 多勒. 柯布西耶本人的性格和他为人处事的 方法，甚至对他进行了心理分析，通过这些 可以看到他的真实性。勒. 柯布西耶认为应 该用最少的物质做最精美的小空间，他把房 子当成个人物品和身体的延伸来思考，一直 在讲节制和美的关系，其实对自然和环境是 非常有贡献的。这个观点我非常认同。

好的作品往往源于创造者主动地加入了 很多思考, 让作品有了无数的解读角度一 并不是只有专家才能解读，而是任何人都可 以去体会。设计师是一个人，他在世间行 走，接受刺激、被触动、产生感想，这些都 被带入设计里，而非体现在理论中。好的设 计师一定是勤于思考的人，一定是对历史、 对自己、对时代高度敏感的人。所以每一次 设计都带着问题，自设问题，自作解答。大 师作品里往往蕴含着深厚的思考, 以及广阔 的“言外之意”。现在中国建筑师在作品里 蕴含的自然、人文社会、技术等方面的内容 也已经越来越多，包括对技术的反思、对自 身的认识、对现实的观察和对传统的探求， 
因而其作品也变得越来越丰满。

我们发现用于传播的建筑图像更侧重于 展示空间设计本身，如尺度、材料细节、节 点等, 较少出现人; 而用于传播的景观图像 则基本都会体现 “人” 的参与，通过人的尺 度呈现场地的使用。您如何评价这种区别?

金：如果景观能主动把“人”加入其 中，在传播上是高明的，这也是非知识系统 化的一个原始状态, 这一点非常好, 一定要 保持。建筑师为什么不这样? 建筑师把建筑 当成一个模型、一张图像，即使出现几个人 也是配景，有时故意把人模糊掉、或做成半 透明, 尽量不影响建筑本身的纯净, 要四壁 皆白。建筑师拍摄建筑的时候爱用冷调，因 为冷调比较酷, 比较理性, 取景的线条也都 是直的，成为了一个“基本标准”。这就是 我在《异物感》 ${ }^{[4]}$ 里批判的把审美工具化、分 析化，审美成为一种分析思维的表达，表达 那种被剥离得干干净净的状态，这是建筑界 的一个大问题。除了用尺规去看世界以外， 建筑师已经忘了如何以人的眼睛来看建筑, 建筑审美被图像和建筑模型反向引导，不是 照片模仿建筑，而是建筑模仿照片，模仿渲 染图。

您如何看待目前地产行业中人们对于商 业化景观模式浪潮的认可，比如新中式、Art Deco之类的风格?

金：任何一个时代都有各种东西一一最 原创、次原创、大众化、末流——这些事物 互相印证。如果到处都是极高等级的艺术,
人人都是毕加索, 我们就根本不需要批评, 也不需要艺术了, 人间就是天堂, 其实也就 是地狱。我觉得对这些事物等闲视之就可以 了, 没有必要去批判它, 因为它们并没有达 到被批评的文化层次，批评关注的也不是这 些内容。

在您看来，是否需要训练设计师的文字 表达能力、培养其理论思维体系的建立，以 使其更具独立思考和批判的意识?

金: 我在教学过程中感受到，真正好的 建筑师, 其设计过程是从视觉到视觉的。外 部世界的有益信息以图像的方式进入他的脑 海，然后在另一个空间里以另一种图像的方 式呈现。我想建筑评论和建筑理论的作用不 在于教设计师用理论思维来思考问题。就像 在设计课上, 我尽量少用语言来描述设计方 法, 用语言来描述感受总是隔靴搔痒, 是次 生的; 感受应该是从眼睛到眼睛, 设计思维 要处于视觉的流动状态。如果做设计的时候 总是想着如何去描述它, 那就不可能做出好 的设计来。

但设计也需要被描述，只有被描述了 才可以成为历史的一部分，因为知识是用语 言来传递的。反过来建筑师在思考设计问题 时，他脑子里也有文字。我们的思想是用语言 来建构的, 当你的语言拓展了, 你就能够想象 原来所想象不到的事物，世界就扩大了。世 界比语言所描绘的大得多，我们眼里的世界 被语言限制着，好在它的边界一直在拓展。 尽管在哲学意义上人类世界的一切皆语言, 但建筑师永远都要有超越文字的能力, 不断 使建筑的形式语言突破文字的界限。LAF
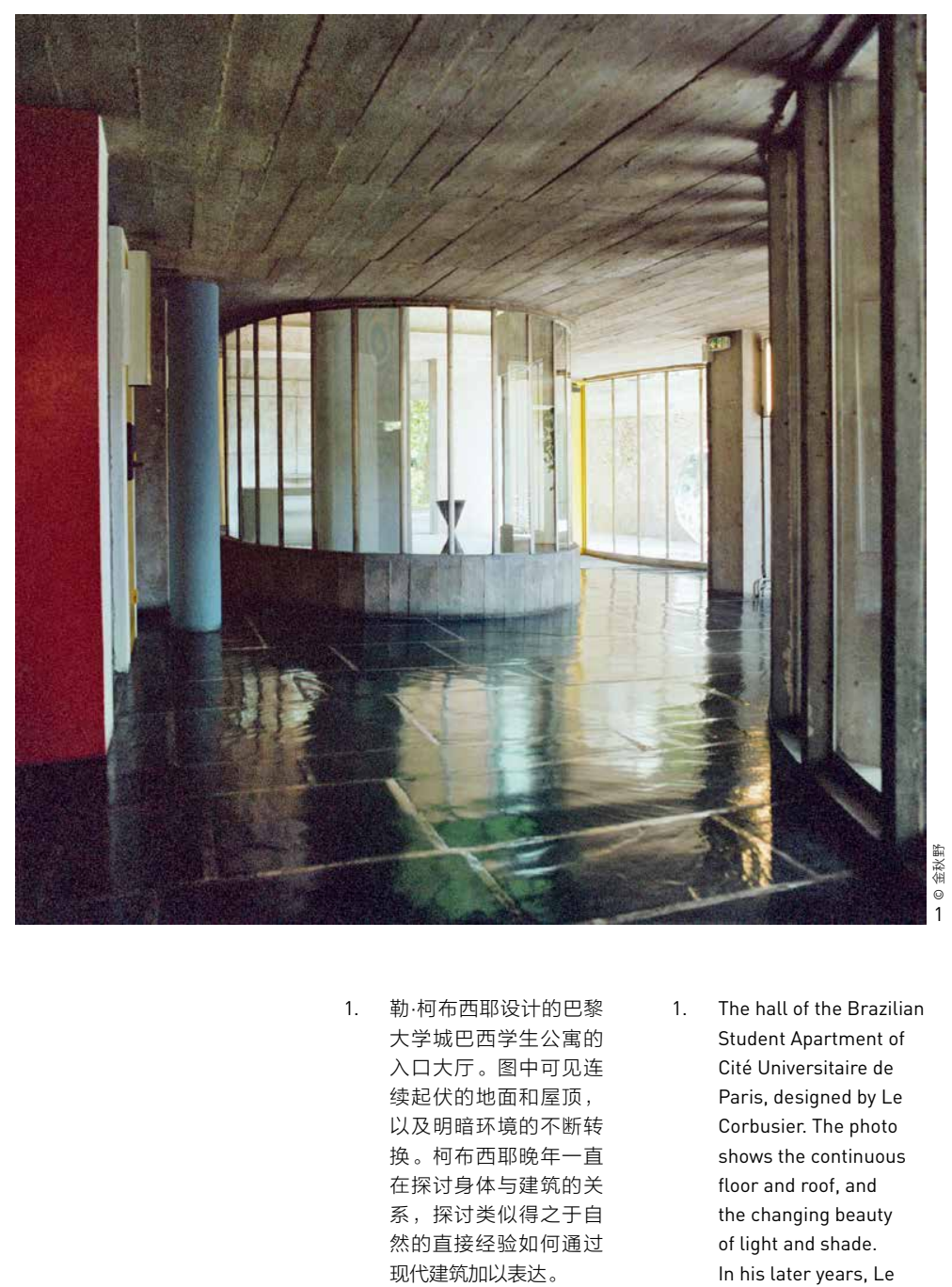

The hall of the Brazilia Student Apartment of Cité Universitaire de Paris, designed by Le Corbusier. The photo shows the continuous flows the continuous the changing beauty of light and shade. In his later years, Le Corbusier explored the relationship between human body and architecture, and how the experience learned from nature can be expressed through modern architecture design. 
Foreign body sensation refers to human's overall feeling and impression on the physical world which is caused by abstraction and de-naturalization and de-naturalization artificial environment.

\section{How do you understand the relationship between architecture and landscape, and the one between human and nature?}

Qiuye JIN (JIN hereafter): It is a big question. How we understand the relationship between architecture and landscape depends on how we understand the relationship between human and nature. On one hand, what distinguishes human beings from other species is we can use tools. Basically, humans' communication is with the aid of tools, such as glasses and lenses. It is safe to say that the human history is also a history of the instrumentalization of human's organs. On the other hand, the two-way exchange between machine and human has been increasingly intensive while the boundary is getting faded. Now artificial intelligence has been applied in many man-made instruments and machines, which are designed with more and more human qualities and behaviors, including perception and reaction. The gap between human and the physical world is bridging.

In most traditional cultures of Eastern countries, architecture and landscape are a kind of extension of human body, through which human connects with nature, layer by layer. From doors and windows that people can see outside scenery and natural landscape paintings or miniature trees that people can enjoy indoor, to backyards or gardens, then to rivers and mountains, each of the layers represents the direct communication between human and nature, also implying the communication through cultural symbols, through human bodies, and through perception and consciousness. Humans shape architecture, and architecture shapes the extended layers of human body. As architecture acts as a medium of connecting human with nature, what architects actually do is to establish a bridge between human and the physical world.

Then it comes to one of the essential questions: What is nature? Philosophically, nature is the circulation of creation and transformation, and the laws of operation and change. The ancient slash-and-burn agricultural practice is more natural than the traditional handicraft techniques, but today's reminiscence is only about celebrating handicraft skills. We have to admit that present-day tools and machines are cold and dull, and this "foreign body sensation" (1) reveals that the development of tools and machines is in a juvenile level. I believe that they will evolve into a sort of creature by natural selection, just like human body. Sooner or later, they will become direct extensive parts of human body, which is inevitable.

In your opinion, what are the similarities and differences between landscape review and architectural review?

JIN: Architecture is about physical building, which would disappear 
eventually. But words remain. I do not think that architectural review is a special subfield of criticism; instead, architectural review stems from architectural professionals' serious work of organizing their thoughts into theoretical words. Everyone has opinions, but not always every opinion is a review. Only if an opinion or a thought is reasonably organized into communicable expression, it is a review. However, it is not to say that organized reviews are definitely better than oral comments.

For example, the new CCTV building in Beijing is figuratively described as "the giant boxer shorts," which I think is impressively brilliant and vivid - street folks may be good at picking nicknames. So review is not an extraordinary thing.

What qualities do you think a good architectural review or critique should have?

JIN: In the article On the Genre of Architectural Criticism ${ }^{[1]}$ published in the Architecture Journal, I argued that a good architectural critique should have clear viewpoints, lucid and literary writing, and no clichés or stereotype genres. Critique is a kind of article, though I do not think the writing skill can be taught or trained. A critic should have keen sensibility and good writing talent. Quite a few recent architectural critiques are too rational which lucubrate and dismember every viewpoint into rigid profiling and segmented argument, ignoring the holistic expression of the article. I think that a good critique needs to reflect a complete life consciousness, the philosophy and critical thinking of the critic, and, the most importantly, true sentiments.

Time is the real critic - there had been countless species on the Earth, but only a few remain over time. Like human's ability of winnowing irrelevant information, anything that spreads is, and will be, tested by time which winnows all the things that without vitality.

\section{Once you argued that criticism} in a way is based on recognition and critics should make their efforts on good works ${ }^{[2]}$. In your opinion, what qualities should a good work have?

JIN: I quoted that from Canran Huang, a great poet and translator. Besides showing recognition on good works, criticism is also to criticize the works that are widely received or thought highly of - I mean critical argument, rather than intentional attack. A lot of bad works appear with an attracting package, and one of the most important yet difficult parts of criticism is to identify the bad works, expound the reasons, and let the public know.

Although there are a plenty of standards to evaluate what good work is, historically, they all regard the same qualities as important. In China, when it comes to poem, we would think of some great poets, such as Li Bai (701762), Du Fu (712-770), Bai Juyi (772846), and Su Shi (1037-1101), the giants in Chinese literature who defined poetry and what we think of poetry. Each artistic profession's development never lacks the contribution from poets and philosophers, say, poets enrich our language as forwards and philosophers ascend our thinking as guards. Therefore, the philosophies and thoughts of good poets, good artists, or good critics need to be generated in a certain macro-historical context. A good work lives and glitters over time, and becomes a new standard of good for the future works; also, a good architect's philosophy germinates and nourishes from the architectural history. Thus, a critique expresses the ctitic's philosophy based on one's historical knowledge and his / her own understanding of time.

Many of your efforts are about introducing Le Corbusier and Alvar Aalto's work into China and reviewing their publications. Is your architectural philosophy influenced by theirs? We noticed that you introduced the book Modern Man: The Life of Le Corbusier, Architect of Tomorrow ${ }^{[3]}$ into China and recently published its Chinese edition. Is it your hope that those architectural classics can be more widely and profoundly studied by contemporary architects? 


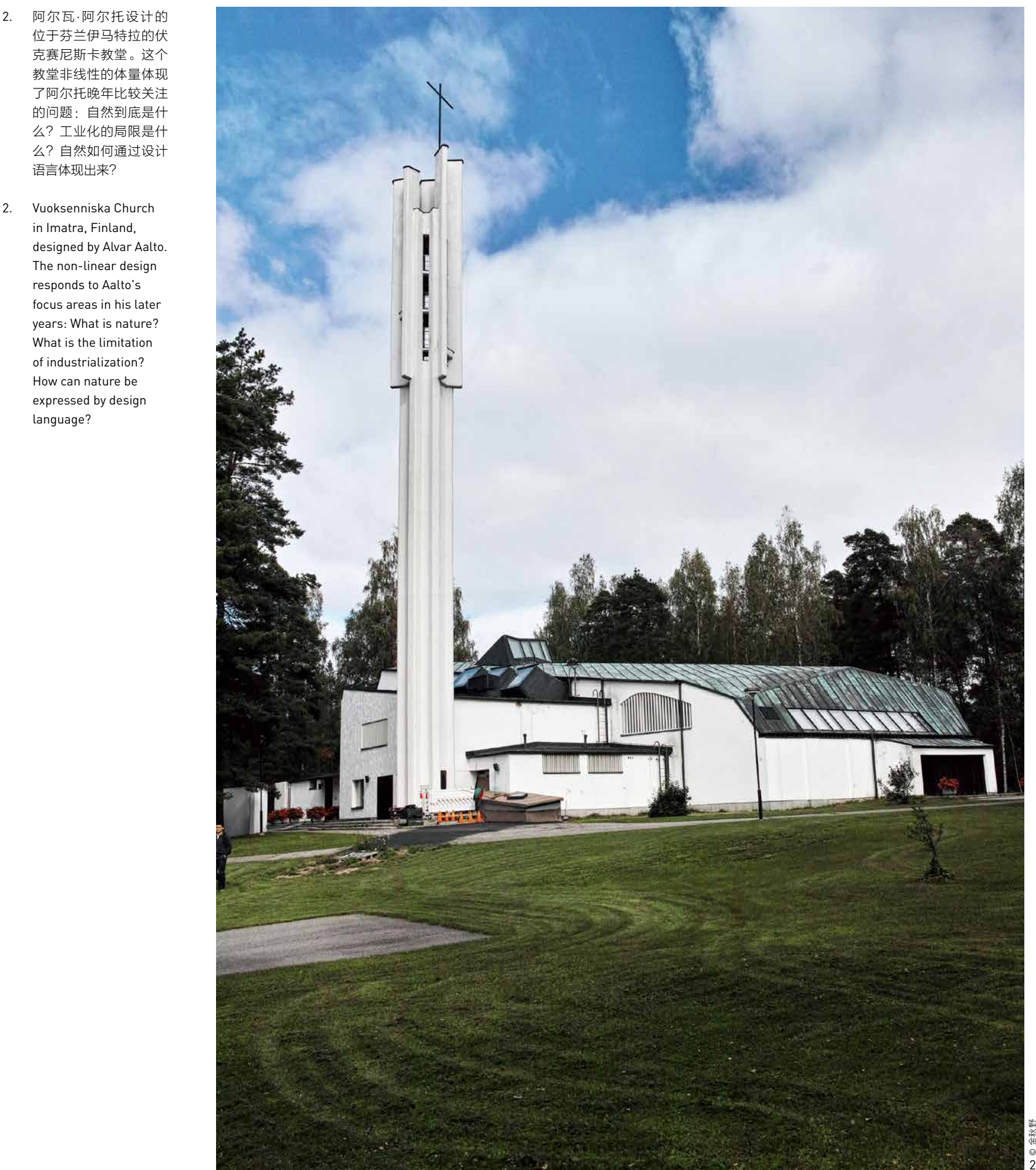

JIN: Many great architects in the earlier 20th century felt puzzled and put forward questions, and attempted to answer with their own design, which offered contemporary architects some inspiring perspectives. Although then they did not encountered some problems of modern cities, such as air pollution, Alvar Aalto did think a lot about the relationship between human and nature and the way for balance. Actually, his questions were answered by both his thinking and design already.

I position the book Modern Man: The Life of Le Corbusier, Architect of Tomorrow as a bestseller, because it is very important for the public to know the architect. In China, people know Dali, Picasso, Tchaikovsky, and other prominent modern artists, but few people know Le Corbusier. Architects' public influence is still too small — actually not many of them have the desire to communicate with the public. I chose and translated this biography because of its high narrative. It talks about Le Corbusier's character and his social life, even includes a psychological profile. All the details of his life offer us another way to understand his work. Le Corbusier held that we should use minimal materials to build the most exquisite small spaces. He regarded houses as personal belongings and extension of human body, and emphasized the relationship of temperance and beauty, which is consistent with the idea of natural and environmental protection 
and I highly admire.

A good work needs to be created with meaningful ideas that allows the work to be understood and interpreted variously by ordinary people, not only by experts. A designer, as a person, lives in the world, who perceives and is affected, and reflects all the feelings into the design, instead of concluding them from the perspective of theory. A good designer must be diligent in thinking and highly sensitive to history, to personal emotion, and to time changes; one's design should start from a question, then explore and answer through the work itself. Masterpieces often reflect profound meaning and broad implication. Nowadays the works by Chinese architects increasingly focus on the topics ranging from nature, history and culture, to technology, showing their rethinking on technology, individual philosophy, social reality, as well as tradition and innovation.

\section{We found that architectural images} tend to focus on spatial design itself. For instance, most typical architectural photos spotlight on the mass, material details, and spatial nodes of a building, rarely showing how people live in or use the space. However, in most landscape graphic materials, spatial design is demonstrated by how people use the site. What is your comment on this distinction?

JIN: It is smart to add people in

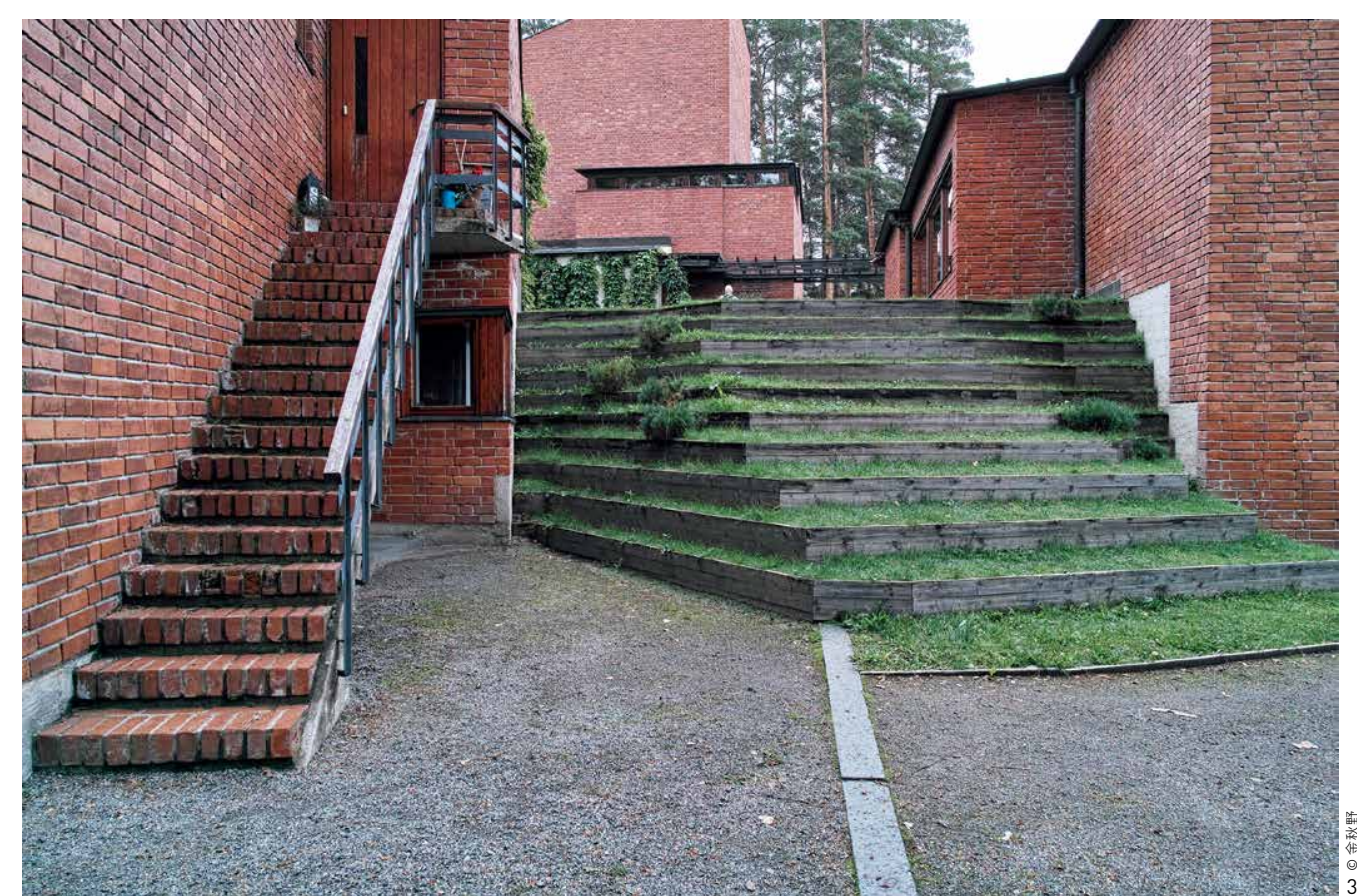

graphic materials and it is a primitive yet wonderful state of non-systematization of knowledge. But why do not architects do that? From an architect's viewpoint, architecture is a sort of object, a show-case image; in most cases, people are regarded as a kind of background, sometimes being processed as blurred or translucent figures in order to not impact the purity of the building itself, for example, to keep all walls clean. I also found that most architects prefer using cold tune and straight view line when taking pictures of a building, since they believe that cold tune and straight lines mean cool and rational, which is a kind of industrial rule in architecture and what I called "instrumentalization or dissection of aesthetics" in my book Foreign Body Sensation ${ }^{[4]}$. Instrumentalization or dissection of aesthetics refers to an expression of analytic thinking and a purely clean state. I am afraid that this is a serious problem in contemporary architectural profession: architects forget how to look at the world with their own eyes and their aesthetics is largely influenced by architectural images and models, resulting in that their realistic design becomes photo- or rendering-fashion buildings. 
3. 阿尔瓦.阿尔托设计的珊 那特塞罗市政厅二层庭 院台阶入口

4. 阿尔托自宅起居室

3. The terrace entrance of the Säynätsalo Tow Hall, designed by Alvar Aalto.

4. The living room of the Aalto House
What do you think of the popular design waves of commercial landscape, such as Neo Chinese-style and Art Deco Style, in the current real estate development?

JIN: Every age has its own inclusiveness, no matter of the original and the imitator, or the popular and the inferior, they all exist and set off the other. If there were fine art everywhere and everyone was a master, then we do not need criticism or art at all - a world full of high art is the heaven, but also the hell. I think we could make light of these design waves, and there is no need to criticize them, because they are not culturally important to be considered in criticism.

In your opinion, is there a necessity to train designers' literary competence and enrich theoretical knowledge system to foster their consciousness of independent and critical thinking?

JIN: My teaching experience taught me that a good architect's work is from visual to visual. One can turn useful information from the physical world into mental images, then visualizes them in another space. Studying architectural criticism and architectural theory does not aim at training designers to think

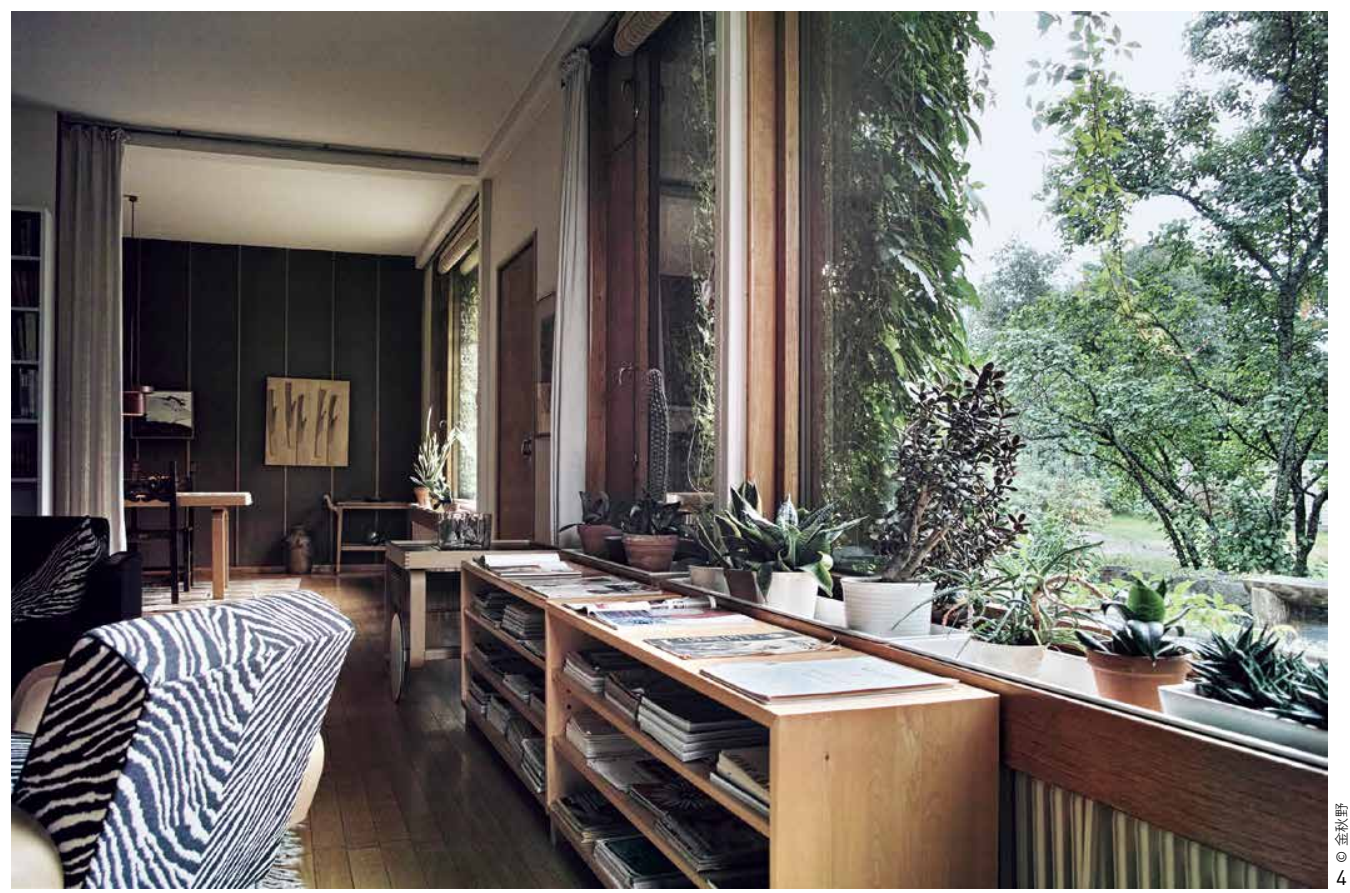

theoretically. In my design class, I ask students to learn by watching, rather than listening. Because language passes secondhand information, and what a designer really needs is to think visually and dynamically. If a designer always thinks about how to describe while designing, his / her design will be messed up.

Yet design also needs to be described, because knowledge is spread by language. Architects, in turn, have words in their mind when thinking about design problems. Our philosophy and thoughts are built with words.

Language exploration expands our imagination. The world is also built with words, which is broader and much more tremendous than what we have known - luckily humans are expanding its borders all the time. Although, philosophically, everything in the human world is a language, architects always need to have the ability to transcend the limits of words through their design language. LAF

\section{REFERENCES}

[1] Jin, Q. Y. (2017). On the Genre of Architectural Criticism. Architectural Journal, (8), 112-113.

[2] Jin, Q. Y. (2014). In Search of an Architectural Criticism Language: Honestly Facing the Reality of Today's China. World Architecture, (8), 80-81.

[3] Flint, A. (2017). Modern Man: The Life of Le Corbusier, Architect of Tomorrow. Shanghai: Tongji University Press.

[4] Jin, Q. Y. (2017). Foreign Body Sensation. Shanghai: Tongji University Press. 